\title{
KORUPSI KOLUSI DAN NEPOTISME DALAM PERSPEKTIF HUKUM ISLAM
}

\author{
Oleh : Dahlia H. Ma'u
}

\section{Pendahuluan}

Di tengah hirup pikuk pergaulan manusia yang melibatkan pelbagai kepentingan dan tingkat kekuatan individu atau kelompok diperlukan sarana kontrol sosial yang menjamin tidak adanya perilaku manusia yang mementingkan kepentingan sendiri dan berakibat merugikan orang lain. Kehadiran hukum ditengah masyarakat memiliki arti penting karena hukum menvediakan aturan hidup bei`sama dan menjadikan keadilan untuk semua. Namun persoalannva hukum dan keadilan itu sendiri tidak jarang dihadapkan pada tantangantantangan praktis. Adanya hukum yang tidak dapat ditegakkan terhadap orangorang besar seperti para penguasa dan para kroninya bahkan telah menjadi fenomena hukum sejak dahulu kala, terbukti Nabi Muhammad SAW, pernah menunjuk hal ini sebagai persoalan yang harus diberantas. Tetapi ternyata hingga sekarang ini persoalan tersebut belum dapat selesaikan, bahkan masih terjadi di negeri-negeri yang dikenal sudah maju dan dipandang sudah dapat menj alankan prinsip-prinsip demokrasi dan hak-hak asasi manusia untuk masyarakat, seperti Amerika, Inggris, bahkan Indonesia.

Di dalam perjalanan bangsa kita untuk mewuj udkan tuj uan sebagai mana dimaksudkan dal am Preanibtile UUD 1945, ternyata telah ditemukan berbagai kendala, hambatan dan tantangan yang sangat mendasar antara lai praktek korupsi, kolusi dan Nepotisme di tengahtengah masyarakat kita. Praktek korupsi, kolusi dan Nepotisme sangat membahayakan eksistensi negara dan merusak sendi-sendi kehidupan masyarakat, berbangsa, bahkan ini sampai merusak integritas bangsa, oleh karean itu diperlukan langkah langkah yang bersifat strategis serta upaya-upaya koni4krit untuk memberantas penyakit yang tumbuli dengan subur di tengah-tengah kehidupan masyarakat.

Belakangan ini media massa gencar memberitakan fenomena kekerasan dan main hakim sendiri terhadap prilaku kriminal, sudah banyak korban yang tewas akibat dihakimi massa. Int semua berakibat kurangnya kepercayaan masyarakat terhadap penegak hukum. Olehnya diperlukan upaya untuk melaksanakan supreamasi hukum 
dengan mengembalikan dan munumbuhkan kepercayaan masyarakat kepada hukum dan penegak hukum.

Hukum Islam dengan karakteristik ke universalannya, menjadi sumber pengambilan dasar-dasar hukum yang meletakkan prisnsip-prinsip keadilan, keamanan social di setiap dimensi kehidupan. Wacana hukum Islam dalam hal korupsi, kolusi dan nepotisme dipahami lewat istilah Risywah ( Suap ), Saragoh ( Pencurian), at-Qasysyh (Penipuan ) dan Khianat (Penghianatan). Bahkan moral dan kemanusiaan yang sarat dengan etika dan prilaku hukum itu secara jelas terkandung dalam sumber ajaran Islam, al-Qur'an dan as-Sunnah.

\section{Korupsi, Kolusi dan Nepotisme dalam perspektif hukum Islam}

\section{a. Definisi Korupsi, Kolusi dan Nepotisme ( KKN )}

1stilah korupsi berasal daribahasa latin Corruplio atau Corruplus yang artinya : Busuk, buruk, bejad, dapat disuap, menyimpang dari kesucian, perkataan yang menghtna atau memfitnah. ${ }^{1}$

Sedangkan dalam bahasa Ingg,ris dikenal dengan istilah Corruption, artinya : Korupsi, kecurangan. ${ }^{2}$

Dalam Kamus Besar Bahasa Indonesia, korupsi diartikan sebagai penyelewengan atau penggelapan ( uang negara atau perusahaan dsb) untuk keuntungan pribadi atau orang lain. ${ }^{3}$

Selanjutnya dalam literatur keislaman, istilah korupsi identik dengan Risywah atau Rasywah yang berarti : Suap atau pemberian sesuatu kepada seseorang karena ada maksud menytiap. ${ }^{4}$

\footnotetext{
${ }^{1}$ Andi Hamzah, (Ed), Bunga Rampai Hukum Pidana dan Acara Pidana, (Cet. I : Jakarta : Ghalia Indonesia, 1986 ), h. 197

2 Jhon. M. Echlos, Hassan Sadily, Kamus Inggris Indonesia, (Cet. XXIII : Jakarta : PT. Gremesia Pustaka Utama 1996 ), h.149

${ }^{3}$ Departemen Pendidikan dan Kebudayaan, Kamus Besar Bahasa Indonesia, (Cet. III, Jakarta : Balai Pustaka, 1994 ), h. 527

${ }^{4}$ M. Abdul Mujieb, et. Al, Kamus Istilah Figh (Cet. I, Jakarta : PT. Pustaka Firdaus, 1994 ), h.294
} 
Berdasarkan definisi diatas, dipahami bahwa korupsi adalah salah satu bentuk pelanggaran hukum, yaitu perbuatan pen yalahgunaan wewenang, penyalahgunaan kekuasaan dan menggunakan kesempatan untuk kepentingan pribadi atau oranglain.

Selanjutnya istilah kolusi dalam Kainus Besar Bahasa Indonesia, berarti: Kerjasama rahasi untuk maksud terpuji, persekongkolan. ${ }^{5}$ Dalam Bahasa Inggris disebut artimya persekongkolan, kongkalingkong. ${ }^{6}$

Dalam istilah al-Qur'an kolusi termasuk Ta'awun 'ala al-Itsini wa al-Udwan ${ }^{7}$ yaitu suatu bentuk kerja sama dalam melakukan kejahatan.

Kermudian nepotisme, berarti: kecendrungan untuk mengutamakan (menguntungkan) sanak saudara sendiri, terutaina dalarn jabatan, pangkat di lingkungan pemerintah. ${ }^{8}$

Dalam istilah arab dikenal dengan "atsarat at-aqarab ".9 Dalam tataran definisi diatas, istilah KKN (korupsi, kolusi dan Nepotisme) masih dapat dibedakan, korupsi lebih berkonotasi penyalahgunaan kepentingan umum (Mashalih Aminah), (termasuk di dalamnya negara, pemerintah, masyarakat atau organisasi/perusahaan) untuk kepentingan pribadi atau sekelompok orang. Sedangkan kolusi cenderung berkonotasi penyalahgunaan kedudukan, wewenang dan jabatan, untuk mewujudkan maksud dan kepentingan sekelompok orang yang berkepentingan sama. Adapun Nepotisme berkonotasi pada pengutamaan kerabat dekat dalarn pengangkatan suatu kedudukan dalarn pemerintahan atau perusahaan. ${ }^{10}$

Berdasarkan uraian diatas, bahwa korupsi, kolusi dan Nepotisme, merupakan istilah yang dipakai untuk menunjukan pada suatu bentuk pelanggaran hukum dan dapat disebut sebagai penyakit dalam pembangunan bangsa dan negara.

Perspektif hukum Islam terhadap korupsi kolusi dan Nepotisme Secara teoritis kedudukan korupsi, kolusi dan nepotisme, khususnya korupsi merupakan

\footnotetext{
${ }^{5}$ Departemen Pendidikan dan Kebudayaan, Op.Cit., h.514

${ }^{6}$ Jhon. M. Echlos, Op.cit., h. 125

${ }^{7}$ QS.AI-Maidah / $5: 2$

${ }^{8}$ Departemen Pendidikan dan Kebudayaan, Op.Cit., h.687

9 Lihat, Faturrahman Djamil, KKN dalam perspektif hukum dan moral Islam, Dalam Mimbar

${ }^{10}{ }_{\text {Ibid. }}$
} Hukum, No. 42 tahun X 1999), h. 63 
tindakan krim i nal (Jinayah atau Jarimah). Asas legalitas hukum Islam tentang korupsi sangat jelas dan tegas. Sebagi suatu delik pencuri an, pelaku korupsi hams dihukum. Lebih jauh makna "potong tangan" dalam ayat yang menjatuhkan sanksi bagi pencuri lebih menunjukan esensi perbuatan korupsi itu sendiri. Melalui korupsi pelakunya memotong kesempatan orang lain dengan cara tidak sah dan melawan hukum. Memotong peluang dan kesempatan usaha dengan cara suap, monopoli ataupun tindakan pernerasan. ${ }^{11}$

Islam melarang tindakan suap menyuap sebagai suatu perbuatan yang dikutuk atau dilaknat Allah SWT, dalam hadits Rasulullah SAW, disebutkan : "Dari Abu Hurairah ia berkata, Rasulullah SAW, bersabda : "Laknat Allah akan menimpah orang yang menyuap dan menerima suap dalam hukum." (FIR. Ahmad, Abu Daud dan Tirmidzi ) ${ }^{12}$

Pada hadis yang lain disebutkan :Dan dari 'Abdullah bin Ann' ia berkata, Rasulullah SAW, bersabda "Laknat Allah akan menimpah orang yang menyuap dan menerima suap" (HR. Lima Imam, Kecuali Nasa'i dan disahkan oleh Tirmidzi ). ${ }^{13}$

Menurut as-Syaukani, bahwa hadiah kepada hakim dan sebagainya, itu adalah sebuah bentuk Risywah.

Sebab seorang yang memberi hadiah kalau belum merupakan kebiasaan kepada hakim sebelum diangkat sebagai hakim, sudah pasti hadiahnya itu ada tendensi tertntu. Mungkin untuk memperkuat kebatilannya atau sebagai upaya mencari kemenangan. Semuanya itu adalah haram. ${ }^{14}$

Dengan demikian perbuatan risywah (suap), merupakan perbuatan yang secara jelas dilaknat Allah dan diharamkan melakukannya. Dalam al-Qur'an telah disebutkan secara jelas, yaitu pada QS. an-Nisa /4 : 29 " Hai orang-orang yang beriman janganlah kamu saling

${ }^{11}$ Lihat, Munawaar Fuad Noer, Islam dan Gerakan Moral anti Korupsi, (Ed) H. Ahmad Sya'i Mufid, ( Cet. I, Jakarta : CV. Zikrur — Hakim, 1997 ), h. 87

12 as-Syaukani, Nailul Author, Himpunan Hadis - hadis Hukum, Jilid 6, (Surabaya : PT. Bina Ilmu, 1993), h. 3189

${ }^{13}$ Ibid.

${ }^{14}$ Ibid, h.3190 
memakan harta sesarnamu dengan jalan bathil / tidak sah dan tidak etis, kecuali dengan jalan perniagaan yang berlaku dengan suka. sama suka diantara kamu. ${ }^{15}$

Larangan ber-KKN sebagaimana dipahami dari ajaran agama tersebut (al-Qur'an dan Hadits), jelas menunjukan bahwa korupsi, kolusi dan nepotisme melanggar hukum (tidak sah, bathil), berlaku aniaya (dzalim, tidak bermoral), dalam arti merugikan orang lain, dan melanggar Hak Asasi Manusia (HAM) tidak berprinsip kebebasan dan keterbukaan dalam bermuamalah $).{ }^{16}$

Tujuan penetapan hukum dalam Islam, termasuk larangan keras ber-KKN, adalah untuk memelihara kemashlahatan (kebaikan dan kebahagiaan) manusia sekaligus menghindari mafsadat (ketidak mashlahatan, kesengsaraan dan kehancuran di dunia maupun diakhirat. Menurut ahli ushul fiqh, ada lima unsar pokok (dharuri) yang hams dipelihara dan diwujudkan dalam rangka menegakkan tujuan hukum Islam, yaitu: memelihara agama, jiwa, akal, kehormatan dan harta. Jadi memelihara satu diantara lima perkara itu, adalah merupakan kepentingan yang bersifat primer bagi manusia. ${ }^{17}$

Berdasarkan tujuan penetapan hokum Islam tersebut, maka korupsi, kolusi dan Nepotisme jelas melanggar tujuan yang dintaksucl karena korupsi, kolusi dan Nepotisme sebagi tindakan penyelewengan dan menyalahgunakan amanah bangsa dan negara. Sama halnya dengan kolusi dan nepotisme, keduanya melanggar etika dan norma keagamaan.

Dalam hal tindakan nepotisme, Islam memberikan petunjuk mengenai pemilihan dan pengangkatan sesorang untuk menjabat suatu kedudukan atas dasar pertimbangan kapabilitas (kemampuan dan rasa tanggung jawab, profesionalitas, keahlian dan moralitas/Akhlakul Karimah). ${ }^{18}$

Mengenai kapabilitas, profesionalitas dan moralitas, al-Qur'an secara jelas melalui kisah (karir) kenabian Nabi Musa dan Harun AS, membenarkan tiga kriteria tersebut. Dikisahkan bahwa Nabi Musa adalah seorang Nabi yang 'cader. Untuk

\footnotetext{
${ }^{15}$ Departemen Agama RI, al-Qur an dan Tedemahnya, ( Suarabaya : Jaya Sakti, 1989 ), h. 122

${ }^{16}$ Lihat, Faturrahrnan Djamil, op, cit., h.64 $1994)$, h.333

${ }^{17}$ Lihat, Abdul Wahhab Khallaf, Kaidah-kaidah hukum Islam, (Cet. IV ; Jakarta : Raja Grafindo Persada,

${ }^{18}$ Lihat, Faturrahman Djamil, et.al, Menvingkap Korupsi, Kolusi dal? Nepotisme di Indonesia, Pengantar M. Amien Rais, (Cet. I, Yogyakarta : Aditya Media, 1999 ), h.109
} 
menghadapi kediktatoran dan kebiadaban penguasa Fir'aun,beliau perlu melakukan diplomasi dakwah yang persuasif. Lalu Musa memohon(berkolusi positif) kepada Allah untuk mengangkat Harlin saudara kandungnya, menjadi wazir (menteri pembantu dalam berdakwah), karena is dinilai afshah al-lisan (lebih mampu dan profesionalitas dalam berkomunikasi) dan mempunyai moralitas yang baik, berupa ketaatan kepad Tuhan (Imtaq), serta berkesediaan dan bet- keberanian untuk saling memberi nasehat dan peringatan (kontrol moral). ${ }^{19}$

Berdasarkan uraian diatas, dipahami bahwa seorang keivarga dekat dapat saja diangkat menduduki jabatan tertentu, atau diberikan pangkat tertentu dalam bidang pemerintahan, jika memang mempunyai kapabilitas, profesionalitas dan integritas moral yang yang baik. Bukan karena kepentingan dan tujuan yang merugikan pihak lain (masyarakat dan bangsa). Dan tentunya hal inilah yang harus dihindari/diberikan hukuman secara tegas, yaitu berkolusi dan bernepotisme yang negatif.

Selanjutnya pada dasarnya pelaku korupsi, kolusi dan nepotisme merupakan penghianatan terhadap agama. Delik penghianatan terhadap amanat adalah tindakan pengabaian, penyalahgunaan dan penyelewengan terhadap tugas, wewenang dan kepercayaan. Dalam Islam amanat semata-mata menjadi pesan moral keagamaan. Dalam amanat terkandung ukuran nilai baik dan buruk serta sangsi hukum.

Penegasan tentang keharusan menjaga, memelihara dan menegakkan amanat, dijelaskan dalam firman Allah SWT, QS. An-Nisaa ( 4 ) : 58, yaitu:

"Sesungguhnya Allah menyuruh kamu apabila menyampaikan amanat kepada yang berhak menerimnya dan (menyuruh kamu) apabi la menetapkan hukum diantara manusia supaya kamu menetapkan dengan adil. Sesungguhnya Allah adalah Maha Mendengar lagi Maha Melihat. ${ }^{20}$

Dari ayat diatas, diketahui bahwa amanat itu harus ditegakkan sebagai kewajiban dan kesadaran tanpa pandang bulu, berlaku bagi semua komponen bangsa (penguasa dan rakyat) tanpa kecuali.

\footnotetext{
${ }^{19}$ Ibid.,

${ }^{20}$ Departemen Agama, Op.cit., h.128
} 
Dengan demikian hukum Islam dapat memposisikan tindakan korupsi, kolusi dan Nepotisme sebagai bentuk kriminal. Dan para pelakunya dapat disebut sebagai penghianat, penipu, penyuap dan haram bagi mereka ( pelaku KKN ) untuk masuk syurga. Sebagaimana Sabda Rasulullah dalam salah satu hadisnya : "Dari Abu Ya'la Ma'qal ibn Yasar berkata: aku mendengarkan Rasululullah SAW, bersabda : "Seorang, hamba yang di anugerahi Allah jabatan kepemimpinan, lalu ia menipu rakyatnya, maka Allah mengharamkan masuk syurga" ( HR. Bukhari dan Muslim ). ${ }^{21}$

Berdasarkan uraian diatas, dinahami tindakan korupsi, kolusi dan Nepotisme melanggar hukum agama, dan ketiga tindakan ini dengan jelas merugikan orang lain, merugikan lembaga dan negara. Sehingga dengan tegas Islam mengharamkan tindakan tersebut melalui landasan yuridisnya (al- Qur'an dan al-Hadits )

\section{Solusi dan Penanggulangan KKN}

Upaya yang harus dilaksanakan dalam penanggulan korupsi, kolusi dan nepotisme, disamping melaksanakan supremasi hukum yakni dengan mengembalikan dan menumbuhkan kepercayaan kepada hukum dan penegak hukum, bahwa hukum: itu adalah untuk melindungi rakyat, bukan untuk menindas rakyat. Maka diperlukan upaya penanggulangan korupsi, kolusi dan nepotisme melalui dua aspek, yaitu :

\section{Aspek Preventif}

Bahwa masalah KKN adalah multi kompleks dan multi dimensional, oleh karenanya pendekatan dari aspek preventif untuk memecahkan masalah tersebut perlu mendapat perhatian yang sungguh - sungguh. Aspek prefentif dapat dilakukan di dalam berbagai kegiatan, seperti :

Kegiatan pelayanan hukum, yakni dengan cara memberikan penjelasan kepada warga masyarakat menegani bagaimana caranya perpartisipasi dalam pemberantasan korupsi, kolusi dan nepotisme. Demikian pula penyuluhan hukum tersebut dapat dilakukan terhadap aparatur negara dengan pcnekanan khusus terhadap betapa bahayanya praktek kolusi, korupsi dan nepotisme, sehingga penyuluhan hukum itu,

\footnotetext{
${ }^{21}$ Munawwar Fuad Noeh, op.cit., h. 90
} 
diharapkan dapat menumbuhkan kesadaran hukum, serta menumbuhkan sikap malu berbuat salah.

Kegiatan pertimbangan hukum, yakni dalam bentuk memberikan nasehat dan pertimbangan kepada instansi pemerintah, BUMN, BUMD. Sehingga nasehat dan pertimbangan hukum yang di lakukannya secara proporsional dan profesional diharapkan dapat dicegah dengan tumbuhnya praktek korupsi, kolusi dan nepotisme yang merugikan keuangan negara.

Kegiatan tindakan hukum lainnya, yakni melalui mediator diantara instansi pemerintah. Dan peran mediator ini dapat dilaksanakan dalam usaha menyelesaikan masalah diluar pengadilan, serta mencapai penyelesaian secara menguntungkan semua pihak (win-win solution)

\section{Aspek Represif}

Aspek represif dalam pemberantasan korupsi, kolusi dan nepotisme melalui upaya :

Penegakkan hukum, yakni dengan menggunaka instrumen pidana khusus, sesuai dengan kewenangan yang diberikan oleh peraturan perundang-undangan yang ada. Dan ada kaitannya dengan maksud tersebut, maka pemerintah telah menerbitkan undang-undang No.31 tahun 1999 tentang pemberantasan tindak pidana korupsi.

Selanjutnya menurut Prof. Dr. Emil Salim dalam Rubrik " Forum" Tabloid Jum'at mengemukakan bahwa perlu adanya gerakan nasional anti korupsi, dengan menegakkan krida kabinet pembangunan yakni menegakkan pcmerintahan yang bersih clan berwibawa disamping itu upaya lainnva adalah adanya tarnsparansi di segala bidang dan diperlukan sifat efektif dan represif, bila terbukti seorang pejabat melakukan korupsi, maka harus ditindak, tidal; perlu dibuat peraturan yang baru lagi. Dan perlu adanya budaya malu dan diturnbuhkannya budaya bersalah. ${ }^{22}$

Dalam hal ini diperlukan upaya pembinaan moral dan mental umat manusia. Kesadaran mengenai pentingnya pendidikan moral dan mental tersebut bisa saja tumbuh dari individuindividu, yang kemudian menerapkannya dalam kehidupan keluarga dan masyarakat.

\footnotetext{
${ }^{22}$ Lihat, Tabloid "Juin 'at" 6 Robiul Awwal 1418 H / 11 Juli 1967, nomor 281 / TH VIII,h.2
} 
Pemerintah harus mengambil inisiatif untuk mewujudkan sebuah pola pemebinaan dan pendidikan moral serta mental bagi masyarakat. Hams ada aturan dan kebijakan yang disusun untuk menjadi pedoman bagi rakyat. Seperti apa yang dilakukan Rasulullah SAW, ketika senantiasa secara intensif mendidik dan menatar kepribadian tunatnya dengan sikap Zuhud, Wara' ( taat kepada Allah), menjaga harga diri, terpercaya, mendahulukan kepentingan orang takut kepada Allah, tidak suka melampiaskan ambisi kekuasaan dan tidak haus kekuasaan.

Kemudian dalam rangka menegakkan mekanisme kontrol sosial yang efektif, diperlukan pemberdayaan hukum yang hanya berpihak kepada kebenaran dan keadilan. Sejarah telah memberikan pelajaran bagi kita betapa tegaknya kebenaran dan keadilan hukum menjado faktor terpenting dalam mewujudkan tatanan sosial yang baik. Nabi SAW, telah merintis apa yang disebut Nizham al- Hisbah (semacam lembaga pengawasan ). Dimasa Umar 1bn al- Khattab, lembaga ini sangat berperan dalam kehidupan berbangsa dan bcrnegara. Melalui lembaga ini, Ungar menindak togas pedagang yang cu rang, menimbun barani, spekulan yang membuat harga dipasar tidak stabil, dan scbagainya. ${ }^{23}$

Dari uraian diatas bahwa diperlukan lembaga pengawasan sebagaimana yang dibentuk oleh Nabi Muhammad SAW. Tentunya dengan adanya lembaga ini dapat berfungsi sebagai lembaga pengawasan secara individual dan Nasional.

Dengan demikian melalui upaya-upaya yang disebutkan diatas, maka intinya adalah mereformasi iman dun akhlak semua komponen bangsa melalui fungsionalisasi ibadah ritual, yang ditindak lanjuti dengan amal sosial yang bermoral permberdayaan hukum yang benar dan adil, nasionalisasi gerakan amar ma'ruf nahl munkar dalam arti yang seluasluasnya, dan mekanisme pengawasan sosial yang efektif dan etis.

\section{Penutup}

Berdasarka uraian-uraian yang telah dikemukakan di atas, maka penulis berkesimpulan bahwa :

\footnotetext{
${ }^{23}$ Lihat, Faturrahrnan Djanul, dalam "Mimbar Hukum", Op.cit., h.68
} 
- KKN adalah hal yang primitif dalam diri manusia dan akan selalu ada dan riil. Kelemahan iman dan tcrlalu meniper-turutkan hawa nalsu bisa mengakibatkan terpuruknya sikap moral dan mental yang baik.

- Dalam menciptakan kepribadian moral clan mental yang baik, tidak hanya melalui pemberlaktian Tap. MPR tentang larangan korupsi, kolusi dan Nepotisme, tapi diperlukan pula pemimpin dan komponen bangsa yang terbukti telah terdidik moral dan mentalnya selama bertahun-tahun, telah teruji dan terasah pula dilapangan bukan sekedar mental dan moral yang karbitan semata.

- Untuk mengantisipasi tindakan korupsi, kolusi dan Nepotisme, diperlukan upaya-upaya konkrit berupa pendekatan preventif dan represif bagi kita semua komponen bangsa. Dan diperlukan upaya mereformasi iman dan akhlak pemimpin dan rakyatnya, serta penegakkan kebenaran dan keadilan demi terwujudnya masyarakat, bangsa yang baldatun thayyibatun warabbun ghofur.

- Semoga pemimpin kita dapat menjalankan (melaksanakan amanah dari yang Maha Kuasa Allah SWT. Dan dapat melaksanakan tugas kepemimpinan dengan baik dan benar. 


\section{DAFTAR PUSTAKA}

$\mathrm{Al}$-Qur'anul Karim

Asy-Syaukani, Nailul Author, Himpunan Hadis-Hadis Hukum, Jilid. 6, ( Surabaya : PT. Bina Ilmu, 1993 )

Departemen Pendidikan dan Kebudayaan, Kamus Besar Bahasa Indonesia, (Cet. III, Jakarta: Balai Pustaka, 1994

Departemen Agama RI, al-Qur'an dan Terjemahnya, ( Suarabaya : Jaya Sakti, 1989)

Djamil, Faturahman, et.al, Menyingkap Korzipsi, Kolusi dan Nepotisme di Indonesia, Pengantar M. Amien Rais, (Get. I, Yogyakarta : Aditya Media, 1999) KKN dalam perspektif hukun: don moral Islam. ( Dalam Mimbar Hukum, No. 42 tahun X 1999 )

Echlos, Jhon. M., dan Sadily, Hassan, Kamus Inggris Indonesia, (Cet. XXIII : Jakarta : PT. Gremesia Pustaka Utama 1996)

Hainzah, Andi, (Ed), Bunga Rampai Hukum Pidana clan Acam Pidana, ( Cet. I : Jakarta : Ghalia Indonesia, 1986 )

Khallaf, Abdul Wahhab, Kaidah-kaidah hukum Islam, (Cet. IV : Jakarta : Raja Grafindo Persada, 1994)

Mujieb, M. Abdul, et. Al, Kamus Isaiah Figh (Cet. I, Jakarta : PT. Pustaka Firdaus, 1994)

Noer,Munawaar Fuad ,Islam clan Gerakan Moral anti Korupsi, (Ed) H. Ahmad Sya'i Mufid, (Cet. I, Jakarta : CV. Zikrur Hakim, 1997 )

Tabloid " Jumat 6 Robiul Awwal 1418 H / 11 Juli 1967, nomor 281/ TH VIII. 